\title{
EPILITHIC ALGAE FROM CAVES \\ OF THE KRAKOWSKO-CZESTOCHOWSKA UPLAND (SOUTHERN POLAND)
}

\author{
JOANNA CZERWIK-MARCINKOWSKA, TERESA MROZIŃSKA \\ Department of Botany, Institute of Biology, \\ University of Jan Kochanowski \\ Świętokrzyska 15, 25-420 Kielce, Poland \\ e-mail:marcinko@kielce.com.pl
}

(Received: May 7, 2009. Accepted: October 27, 2009)

\begin{abstract}
This paper describes the first study of algae assemblages in 20 caves in the Krakowsko-Częstochowska Upland (Southern Poland), in the period between 2005-2006. The investigations showed mostly on epilithic algae and their subaeric habitats (rock faces within caves and walls at cave entrances). The morphological and cytological variability of algae were studied in fresh samples, in cultures grown on agar plates and in SPURR preparations. A total of 43 algae species was identified, mostly epilithic species and tolerant of low light intensities. The largest group was formed by representatives of the division Chlorophyta ( 24 species), and then the division Chrysophyta (Heterokontophyta) - 17 species, with 9 species belonging to the class Bacillariophyceae, 7 species - Xanthophyceae and 1 species representing the class Eustigmatophyceae. Dinophyta (2 species) constituted the last and the smallest group. Among the collected algae, the following species deserve special attention: Thelesphaera alpina, Bracteacoccus minor, Trachychloron simplex, Tetracystis intermedia and T. cf. isobilateralis. The last species was not earlier found in Europe. Identification of species was greatly aided by examination of cell ultrastructure, which provided an array of further features, increasing chances of correct species identification.

Furthermore, the studies focused that algae, although usually remaining under dominance of cyanobacteria, excellently differentiate this special area and even enrich it.
\end{abstract}

KEY WORDS: epilithic algae, cave, ultrastructure, Krakowsko-Częstochowska Upland.

\section{INTRODUCTION}

Of autotrophic organisms capable of photosynthesis, living in caves, algae also are worth examining, besides vascular plants and cyanobacteria. They play an important ecological role in this environment as colonisers of rocks are influenced by surface structure, temperature, light and moisture conditions - (Pentecost 1992). Among other things, they are a food source for animals, they are responsible for colored effects on rocky cave walls, which are manifestation of their presence (Golubić 1967).

Algae become almost indiscernible in this environment and difficult to access, due to the cyanobacteria dominance. For this reason, they are little known so far. Therefore, collection of algological materials from 20 caves gives a unique chance to gain fuller insight into algae in this area. These studies were designed to examine only epilithic algae, i.e. those living on cave walls. Abundance of blue greens species, their dominating position in this environment has also been confirmed in Twardowski cave by Starmach (1963) and Mrozińska-Broda et al. (2004). However, all caves from Krakowsko-Częstochowska Upland have also been investigated by geologists (Szelerewicz et al. 1986; Gradziński et al. 1995). In other European countries cave flora is better known by the following authors Claus (1962, 1962a), Kol (1964), Hajdu (1966), Komáromy (1977), Rajczy (1989), Chang and Chang-Schneider (1991), Aboal et al. (1994), Asencio and Aboal (1996, 2000, 2000a), Pentecost and Zhang (2001), Pouličková and Hašler (2007) and Pouličková (2008).

\section{STUDY AREA}

The Krakowsko-Częstochowska Upland is an area higher than the surroundings expanding from Kraków to Wielun cities. Its area is approx. 2500 square kilometres. It is composed mainly of early Jurassic limestone plates. Only in its south-west part some older rocks may be found such as dolomites and Devonian limestone rocks (region of Dębnik Carboniferous limestone, valleys of Szklarka, Racławka, Czernia and Kamienice), dolomites and Triassic limestone (west and north-west from the Eliaszówka valley). The eastern border of the Krakowska Upland Jurassic limestone is covered by Cretaceous sediments. 
The most essential part of landscape of the Upland are denuded limestone rocks. They occur at the slopes of the valleys or in the form of inselbergs. The complex of lime rocks constituting the core of the Upland has the thickness of approx. $400 \mathrm{~m}$. These rocks during millions of years underwent karst processes, which led to formation of numerous sculpted forms both underground and on the surface. Of those the caves are the most interesting. According to Szelerewicz and Górny (1986), there are 220 caves known in the area of the Krakowsko-Częstochowska Upland. The microclimate in some of the caves has been thoroughly examined by Starzecki (1959).

\section{MATERIAL AND METHODS}

Investigations were carried out in the years 2005-2006 in 20 caves located in the Krakowsko-Częstochowska Upland (Fig. 1 and Table 1). All samples were collected from the walls in different parts of caves (I. zone - light zone extends from opening of the cave to the furthest point to which daylight penetrates; II. zone - dark zone from $5 \mathrm{~m}$ to $6 \mathrm{~m}$ deep and III. zone - from $12 \mathrm{~m}$ to $13 \mathrm{~m}$ deep). Algal crusts were scraped using a scalpel into small plastic bags and used directly for observation under a light microscope (JENAMED 2). Part of each samples was introduced into cultures on agar plates at the laboratory. Cultures were in- cubated at $18^{\circ} \mathrm{C}$ under a $16 / 8 \mathrm{~h}$ light/dark cycle at 3000 $\mu \mathrm{Em}^{-2} \mathrm{~s}^{-1}$ provided by $40 \mathrm{~W}$ cool fluorescent tubes; they were examined every 12 days and algae were isolated to obtain pure cultures. Cells were fixed and processed for electron microscopy (TEM) as previously described (Massalski et al. 1995). Observation and photographs were made with a TESLA BS 500 electron microscope. The other part of materials was examined and photographed with scanning electron microscope (Philips LX 30). The identifications of algal taxa were principally accomplished with the aid of the following systematics works: Brown and Bold (1964), Starmach (1966), Brown and Lean (1969), Krammer and Lange-Bertalot (1986), Ettl and Gärtner (1988), Popovský and Pfiester (1990), Krammer and Lange-Bertalot (1991), Ettl and Gärtner (1995).

\section{RESULTS AND DISCUSSION}

Algological studies conducted in 20 caves in the area of the Krakowsko-Częstochowska Upland showed the presence of 43 species of algae (Table 2). A majority of them belonged to the division Chlorophyta (24 species). Representatives of Chrysophyta (Heterokontophyta) constituted the second most abundant group, comprising 17 species, with 9 species representing the class Bacillariophyceae, 7 species the class Xanthophyceae and 1 species belonging to

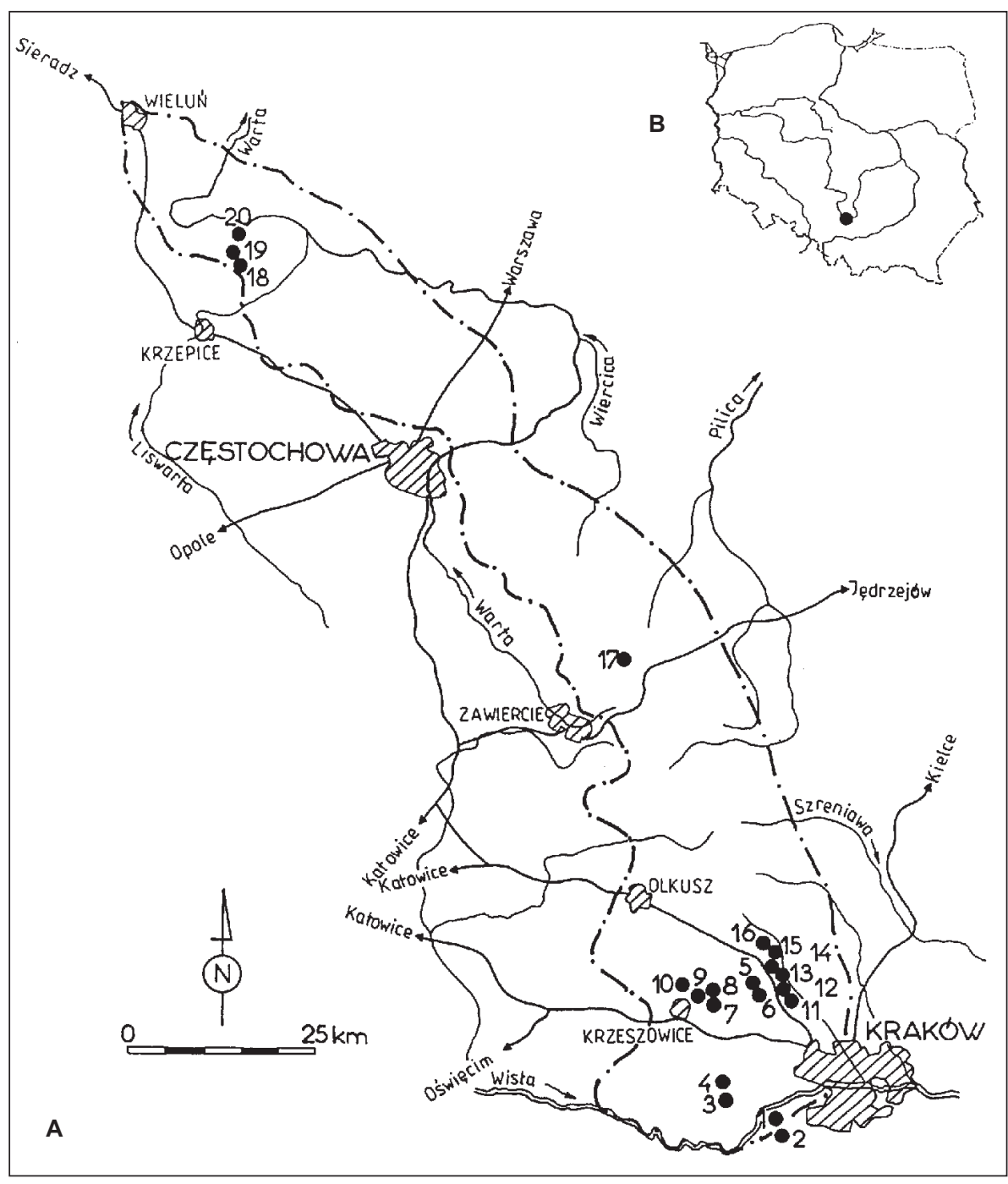

Fig. 1. Map of investigated area: A: distribution of study caves: $\mathbf{1}$ - Jasna Cave; 2 Twardowskiego Cave; 3 - nad Matką Boską Cave; 4 - na Łopiankach Cave; 5 - Mamutowa Cave; 6 - Dzika Cave; 7 - Łabajowa Cave; 8 - Nietoperzowa Cave; 9 - na Tomaszówkach Cave; 10 - Żarska Cave; 11 - Sąspowska Cave; 12 - Zbójecka Cave; 13 Krakowska Cave; 14 - Biała Cave; 15 - Pustelnia Cave; 16 - Schronisko Małe Cave; 17 - Głęboka Cave; 18 - Szachownica I Cave; 19 - Szachownica II Cave; 20 - za Kratą Cave. B: location of the south region in Poland. 
TABLE 1. Morphological characteristics from each of 20 caves of the Krakowsko-Częstochowska Upland.

\begin{tabular}{llclc}
\hline No. & Name of cave & Length & Altitude & Exposition \\
\hline 1 & Sąspowska & $100 \mathrm{~m}$ & circ. $370 \mathrm{~m}$ & $\mathrm{NE}$ \\
2 & Łabajowa & $40 \mathrm{~m}$ & circ. $410 \mathrm{~m}$ & $\mathrm{NW}$ \\
3 & Nietoperzowa & $306 \mathrm{~m}$ & $447 \mathrm{~m}$ & SW \\
4 & Nad Matką Boską & $82 \mathrm{~m}$ & circ. $280 \mathrm{~m}$ & N and NE \\
5 & Żarska & $74 \mathrm{~m}$ & circ. $410 \mathrm{~m}$ & SW \\
6 & Krakowska & $96 \mathrm{~m}$ & circ. $410 \mathrm{~m}$ & NW \\
7 & Mamutowa & $105 \mathrm{~m}$ & circ. $380 \mathrm{~m}$ & SW \\
8 & Dzika & $61 \mathrm{~m}$ & circ. $390 \mathrm{~m}$ & SW and NW \\
9 & Twardowskiego & $430 \mathrm{~m}$ & circ. $215 \mathrm{~m}$ & SW \\
10 & Jasna & $80 \mathrm{~m}$ & circ. $210 \mathrm{~m}$ & $\mathrm{NW}$ \\
11 & Głęboka & $175 \mathrm{~m}$ & circ. $380 \mathrm{~m}$ & NW, SW, N and E \\
12 & Na Tomaszówkach & $100 \mathrm{~m}$ & $435 \mathrm{~m}$ & NE and SW \\
13 & Za Kratą & $70 \mathrm{~m}$ & $215.5 \mathrm{~m}$ & $\mathrm{NE}$ \\
14 & Na Łopiankach & $65 \mathrm{~m}$ & circ. $260 \mathrm{~m}$ & $\mathrm{NW}$ \\
15 & Szachownica I & $600 \mathrm{~m}$ & circ. $215 \mathrm{~m}$ & $\mathrm{E}$ \\
16 & Szachownica II & $200 \mathrm{~m}$ & circ. $157 \mathrm{~m}$ & $\mathrm{NE}$ \\
17 & Biała & $84 \mathrm{~m}$ & circ. $415 \mathrm{and} 424 \mathrm{~m}$ & $\mathrm{NW}$ \\
18 & Zbójecka & $189 \mathrm{~m}$ & circ. $370 \mathrm{~m}$ & NW and W \\
19 & Schronisko Małe & $30 \mathrm{~m}$ & $405 \mathrm{~m}$ & $\mathrm{~N}$ \\
20 & Pustelnia & & $400 \mathrm{~m}$ & SW \\
\hline
\end{tabular}

the class Eustigmatophyceae. Representatives of Dinophyta constituted the last, smallest group ( 2 species).

It was noticed that distribution of algae over the study area was very uneven. In the caves located on an unforested terrain, with marked domination of cyanobacteria, these algae usually were a retreating group (which was very clearly visible in the periods of optimal cyanobacteria development). Their surface, except for scanty patches, was inhabited by cyanobacteria. On the other hand, in caves situated in forested areas, algae, mostly representatives of the division Chlorophyta slightly prevailed over cyanobacteria. The following species dominated in such caves: Tetracystis cf. isobilateralis, T. intermedia, Desmococcus olivaceum, Dilabifilum arthropyreniae, Scotiellopsis terrestris.

Distribution of this group of algae inside the caves was also very characteristic. It was observed that lower, dark parts of the cave (zone II, in the Głęboka Cave taken as an example) were colonized principally by representatives of Xanthophyceae, that were usually accompanied by cyanobacteria. These were: Chlorobotrys terrestris and Chlorobotrys simplex, which developed usually on the areas occupied by cyanobacteria Aphanothece sacola, Diadesmis contenta (a representative of Bacillariophyceae) occurred in humid places. Trachychloron biconicum and Heterococcus caespitosus, representatives of Chrysophyta as well usually occurred in shallower but still dark part of the cave (zone II). They were usually accompanied by cyanobacteria Tolypothrix tenuis var. terrestris, Nodularia sp., Calothrix parietina, Stigonema ocellatum and Nostoc cf. punctiforme. Upper part of the cave (zone I), light, situated near its entrance or slightly further away but lit by reflex light, created beneficial conditions also for epilithic algae. It was covered mostly by Klebsormidium flaccidum, Eustigmatos magnus, Neocystis subglobosa, Bracteacoccus minor and others. Also Trentepohlia aurea, which intensely developed on outer wall of the cave, successfully colonized its inner wall. Humid places even with trickling water inhabited by diatoms (mostly Nitzschia sp. and Pinnularia borealis). In other caves, representatives of the class Dinophyceae, such as Gloeodinium cracoviense and Phytodinium aureum were found in very humid places coexisting with cyanobacteria of the genus Chroococcus, which formed gelatinous clusters. The mentioned species were first found by Starmach (1963) in the Twardowski Cave. They were also recently found in the Nietoperzowa Cave. In addition to the aforementioned species, Leptosira vischerii, Characium strictum, Scotiellopsis terrestris, Tetracystis intermedia and $T$. cf. isobilateralis are also worth mentioning. The last species was not known before to occur in Europe.

According to literature in the field (Etll 1978, Etll and Gärtner 1995, Krammer and Lange-Bertalot 1986, 1991), a majority of algae found in the caves belong to terrestrial algae, i.e. those which exist on earth or to aerophytes, inhabiting tree trunks, surface of rocks or other things. Only some algae, like Trachychloron biconicum and Trachychloron simplex are known to inhabit water biotopes, often rich in calcium ions. Among algae occurring on rock surface (also found in caves), the following species deserve attention: Thelesphaera alpina, Trentepohlia aurea (living mostly on limestone rocks), Hantzschia amphioxys, Luticola mutica, L. nivalis, Orthoseira roseana, etc. Some algae, like Gloeocystis polydermatica and Dilabifilum arthopyreniae, also identified in the caves under study, belong, among other groups, to lichenizing algae. Thus, they occur frequently in caves located on wooded areas. Besides, some algae, like Diadesmis contenta are able to occupy biotopes with strongly reduced light availability. Hence, they have been found exclusively in caves not lit with artificial light and in their darkest parts. Other algae, like Orthoseira roseana and Bracteacoccus minor, upon mass occurrence, form coloured coating on the rock surface. Orthoseira produces brown-yellow deposits while coating composed of Bracteacoccus minor, is orange-red, which is due to the presence of a dye drop in the cells.

Most of algae, found in the caves, are of European origin, occurring not only in the lowlands but also in the mountains, e.g. Klebsormidium montanum, encountered on alpine soils in the Italian dolomites or Scotiellopsis terrestris found as well in the Alps as in the Sudety Mountains and High Tatra Mountains. Leptosira vischerii, an alga species described to occur in Tyrol (Austria), belongs to this group, either. Only some species found in the caves have also been identified on other continents beside Europe, e.g. Leptosira terricola has been found on Signy Island (the Antarctic) and in Canada, Choricystis minor is known from Czech Republic and Japan or Tetracystis intermedia and $T$. cf. isobilateralis have been described to occur in the USA.

It is interesting that among epilithic algae, all abovementioned reports describe mostly representatives of two taxonomic groups, i.e. Chrysophyta (Heterokontophyta) of the classes Bacillariophyceae and Xanthophyceae, and Chlorophyta. Only Claus (1962) mentioned the classes Euglenophyceae, Chrysophyceae and Dinophyceae as well. The last group was also discovered in some caves on the Krakowsko-Wieluńska Upland. Besides, some species, although scanty, like Diadesmis contenta (Navicula contenta), Hantzschia amphioxys, Trentepohlia aurea have been mentioned by almost all authors.

The concept about origin of algal flora in caves, propounded by Claus, is the most convincing. This author suggests that algae migrated from rock surface to caves which allowed them to survive throughout long geological periods and endure the accompanying geologic and climatic chan- 
TABLE 2. Algae composition of caves of the Krakowsko-Częstochowska Upland. Numbers refer to the sites shown in Table 1. + taxa found in caves.

$\begin{array}{lllllllllllllllllllll}\text { Location no. } & 1 & 2 & 3 & 4 & 5 & 6 & 7 & 8 & 9 & 10 & 11 & 12 & 13 & 14 & 15 & 16 & 17 & 18 & 19 & 20\end{array}$

\section{Chlorophyta}

Chlamydophyceae

Chlamydomonas sp.

Tetracystis intermedia (Deason et Bold) Brown et Bold

Tetracystis cf. isobilateralis Brown et Bold

Chlorophyceae

Bracteacoccus minor (Chodat) Petrova

Characium strictum A. Braun

Chlorosarcina longispinosa Chant. et Bold

Choricystis minor (Skuja) Fott

Coleochlamys perforata (Lee et Bold) Ettl et Gärtner

Desmococcus olivaceum (Persoon ex Archerson) Laundon

Dilabifilum arthopyreniae (Vischer et Klement) Tschermak-Woess

Gloeocystis polydermatica (Kützing) Hindák

Interfilum paradoxum Chodat et Topali

Leptosira terricola (Bristol) Printz

Leptosira vischeri Reisigl

Muriella decolor Vischer

Neocystis subglobosa (Pascher) Hindák

Podohedra bicaudata Geitler

Scotiellopsis terrestris (Reisigl) Punčochářová et Kalina

Thelesphaera alpina Pascher

Klebsormidiophyceae

Klebsormidium flaccidum (Kützing) Silva, Mattox et Blackwell

Klebsormidium montanum (Hansgirg) S. Watanabe

Stichococcus bacillaris Nägeli

Stichococcus sp.

Trentepohliophyceae

Trentepohlia aurea (Linné) Martius

Chrysophyta (Heterokontophyta)

Xanthophyceae

Chlorobotrys simplex Pascher

Chlorobotrys terrestris Pascher

Chlorobotrys sp.

Gloeobotrys piriformis Reisigl

Heterococcus caespitosus Vischer

Trachychloron biconicum Pascher

Trachychloron simplex Pascher

Eustigmatophyceae

Eustigmatos magnus (J.B. Peter) Hibbert

Bacillariophyceae

Aulacoseira italica (Ehrenberg) Simonsen

Caloneis silicula (Ehrenberg) Cleve

Diadesmis contenta (Grunow ex Van Heurck) D.G. Mann

Hantzschia amphioxys (Ehrenberg) Grunow

Luticola mutica (Kützing) D.G. Mann

Luticola nivalis (Ehrenberg) D.G. Mann

Nitzschia sp.

Orthoseira roseana (Rabenhorst) O'Mara

Pinnularia borealis Ehrenberg

Dinophyta

Dinophyceae

Gloeodinium cracoviense Starmach (Hemidinium montanum Stein)

Phytodinium aureum Starmach (Phytodinium simplex Klebs)

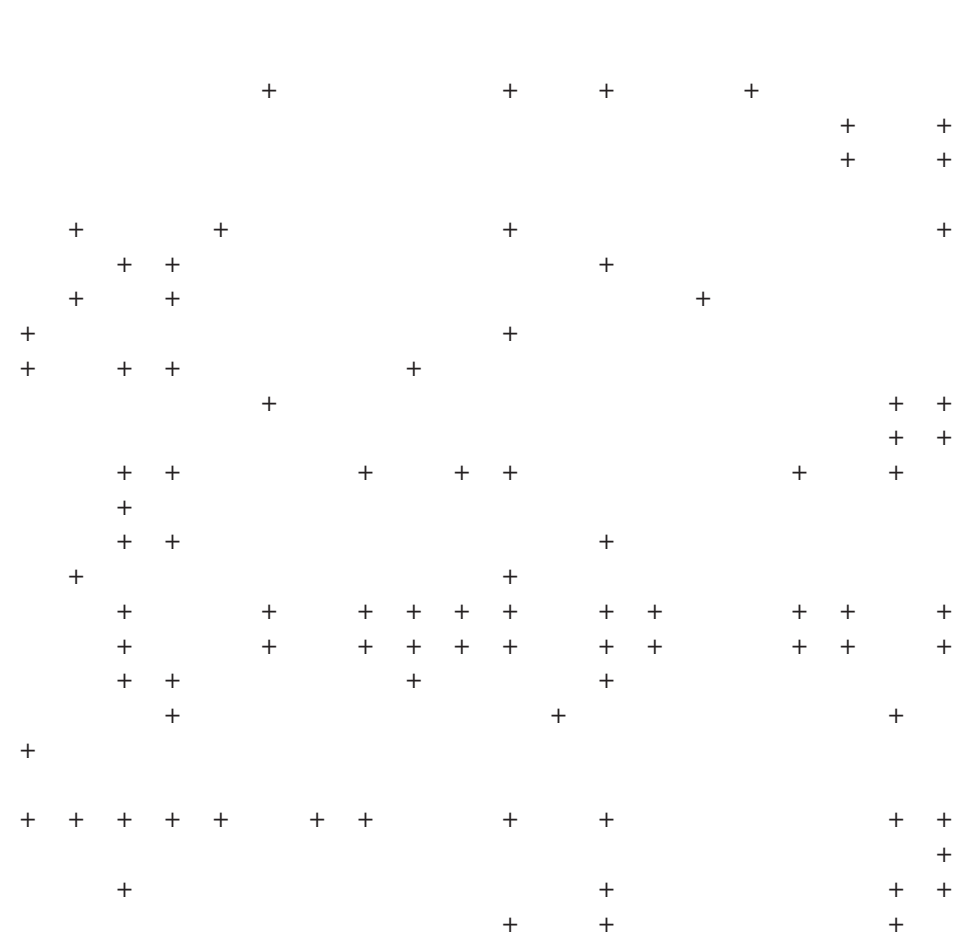

Explanations: 1 - Sąspowska Cave; 2 - Łabajowa Cave; 3 - Nietoperzowa Cave; 4 - Nad Matką Boską Cave; 5 - Żarska Cave; 6 - Krakowska Cave; 7 Mamutowa Cave; 8 - Dzika Cave; 9 - Twardowskiego Cave; 10 - Jasna Cave; 11 - Głęboka Cave; 12 - Na Tomaszówkach Cave; 13 - Za Kratą Cave; 14 - Na Łopiankach Cave; 15 - Szachownica I Cave; 16 - Szachownica II Cave; 17 - Biała Cave; 18 - Zbójecka Cave; 19 - Schronisko Cave; 20 - Pustelnia Cave.

ges. Over these periods, they managed to adapt to existing conditions. New studies conducted by Dodge (1984) on the group Dinophyceae indicated that almost a half of these organisms was obligatorily heterotrophic. Hellebust (1974) drew similar conclusions on the basis of studies on diatoms. He investigated mostly the diatoms living in sediments and indicated that most of them belonged to faculta- tive heterotrophs and could utilize various organic substrates for growth at low light intensities or in dark. Further studies regarding the remaining groups will contribute to better understanding of this problem.

The presented data on epilithic algae are in agreement with results of other authors, like Suba (1957), Claus (1962, 1962a), Jones (1964), Komáromy (1977), Carter 
(1980), Chang and Chang-Schneider (1991), Asencio and Aboal (2000, 2000a). These authors emphasized that epilithic algae are usually scanty in caves because of cyanobacteria domination, due to their excellent adaptation to these conditions. However, also in our view, this is a group of high ecological importance, perfectly characterizing conditions occurring in this specific environment and greatly enriching them.

\section{TAXONOMICAL PART}

\section{- AN OVERVIEW OF SOME INTERESTING SPECIES}

\section{Division: Chlorophyta}

\section{Bracteacoccus minor (Chodat) Petrová (Figs 2-3) \\ Class: Chlorophyceae}

Coenoblasts always globose from 6-38 $\mu \mathrm{m}$ in diameter. Numerous, parietal, plate-like chloroplastes. Adult cells contained orange-red oil droplets. Appears to be more cosmopolitan, known as aerophytic algae, occurr in various soils.

This species occurred in the Łabajowa Cave, Żarska Cave, Głęboka Cave and Pustelnia Cave. In Europe, it is known principally as an overground alga. In Japan, it occurs as an aerophyte on Typha sp. and on tree bark.

\section{Klebsormidium montanum (Hansgirg) S. Watanabe \\ Class: Chlorophyceae}

Filaments uniseriate, vegetative cells cylindrical (7-9 $\mu \mathrm{m}$ broad, 6-7 $\mu \mathrm{m}$ long) with parallel sides in younger filaments becoming barrel-shaped in older ones. Single, ringlike parietal chromatophore with one pyrenoid with many starch grains.

This species was found in the Pustelnia Cave. Besides, it is known from Sweden, Italy (from the Dolomites in southern Tyrol) and from Japan (Ettl and Gärtner 1995).

\section{Muriella decolor Vischer (Figs 4-7)}

Class: Chlorophyceae

Vegetative cells singel, spherical or globose, 3.7-7 $\mu \mathrm{m}$ in diameter, covered by thin cell wall. Chloroplast parietal, in young cells cup-shaped. During the growth of the cell becoming divided into 2. Chloroplast in adult cells always 2, bay-shaped.

This species occurred in the Krakowska Cave, Głęboka Cave, Nietoperzowa Cave, Biała Cave, Zbójecka Cave, Na Łopiankach Cave, Za Kratą Cave, Jasna Cave, Twardowskiego Cave, Dzika Cave and Pustelnia Cave. It is known as an aerophytic algae from Switzerland and Czech Republic but it was found for the first time growing in a soil habitat (Massalski et al. 2001).

\section{Podohedra bicaudata Geitler}

Class: Chlorophyceae

Vegetative cells broadly spindle-shaped to oval (4.3-6.0 $\mu \mathrm{m})$, running straight or curved, 17-21 $\mu \mathrm{m}$ long. Apical part ending with a very short tip, at the narrowed with one short stik and fastendisc. Chloroplast parietal with pyrenoid surrounded by starch grains.

This species occurred in the Nietoperzowa Cave, Twardowskiego Cave, Za Kratą Cave and "Nad Matką Boską"
Cave. Until now, it was known only from Austria (Bad Ischl.). In mucilage on the surface of old Pinus branches.

\section{Scotiellopsis terrestris (Reisigl) Punčochářová et Kalina}

Class: Chlorophyceae

Vegetative cells spindle-shaped, slightly asymmetric. Cell wall think on the poles with 6-12 (rarely more) ribs, running straight or slight spiral, weakly visible. Chloroplast parietal, at the beginning single, later lobed or divided to pieces with pyrenoid surrounded by numerous starch grains. Vacuoles only in old cells.

Previously recorded from soils of Alps (Austria, Italy) (Ettl and Gärtner 1995), High Tatra Mountains (Slovakia), Sudeten (Czech Republic) and Barunschweg (Germany). It was found in following caves: Nad Matką Boską Cave, $\mathrm{Na}$ Tomaszówkach Cave and Schronisko Cave.

\section{Tetracystis intermedia (Deason et Bold) Brown et Bold} Class: Chlamydophyceae

Mature vegetative cells - spherical, 12-20 $\mu \mathrm{m}$ in diameter. Chloroplast containing a single, excentric, ellipsoidal pyrenoid, surrounded by 2 half-globose starch grains. Vegetative cell with 2 contractile vacuoles.

This species was found in the Zbójecka Cave and Pustelnia Cave. It was first distinguished by Deason and Bold (1964) and called Chlorococcum intermedium in North America (Texas). Besides, it is also known as overground species occurring in Tyrol (Italy), Japan and Russia.

\section{Tetracystis cf. isobilateralis Brown et Bold (Figs 8-9)}

Class: Chlamydophyceae

Young cells ellipsoidal, mature vegetative cells - spherical to subspherical, $18-19 \mu \mathrm{m}$ in diameter, in groups of 2-4 cells (formed diad or tetrads). Chloroplast - massive, somewhat mottled, almost filling the whole cell lumen with a single, large central pyrenoid (with parallel lamellae), irregularly shaped and surrounded by many starch plates. Disc system is more variable. No definite reticulation between disc systems. Mitochondria cylindrical, large, ribbon like and frequently branched.

This species was found in the Zbójecka Cave and Pustelnia Cave, where it coexisted with the former species. Up till now it has been known as an overground alga only from Texas (North America).

Thelesphaera alpina Pascher (Fig. 10)

Class: Chlorophyceae

Vegetative cells single, ellipsoidal, mainly flat, only sometimes spherical 10-12 $\mu \mathrm{m}$ in diameter. Cell wall slightly thick with great, nearly half spherical emergences, arranged by three (or more) on each apex or between coming out radial. Chloroplast parietal, bay-shaped to ring-like. This species was found in the Sąspowska Cave. It is known also as an epilith growing on rocks in Steiermark and Tyrol (Austria), also Romania (Caraus 2002).

Trachychloron simplex Pascher (Fig. 11) Division: Chrysophyta (Heterokontophyta)

Class: Xanthophyceae

Vegetative cells 5-7 $\mu \mathrm{m}$ broad, 8-10 $\mu \mathrm{m}$ long.

Calciphilous species. It occurred in the Mamutowa Cave. It was known only from old river-bed of the River Traun (Austria) and from a pond near Prague (The Czech Republic). 

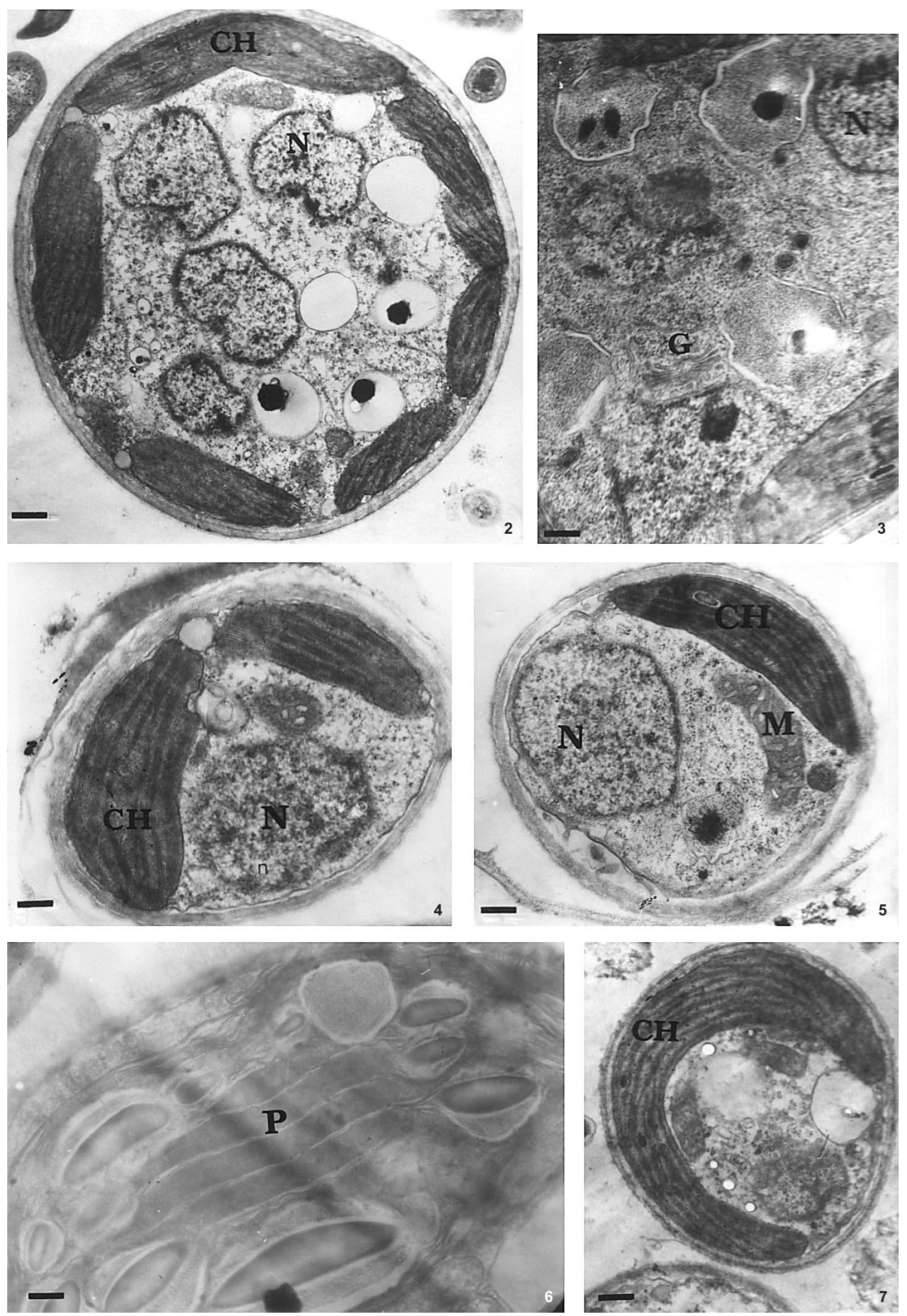

Figs 2-13. Transmission electron microscopy (TEM) of vegetative and reproductive stages of epilithic algae in stady caves (ch - chloroplast; $\mathrm{g}$ - Golgi body; $\mathrm{m}$ - mitochondrion; $\mathrm{n}$ - nucleus; $\mathrm{p}$ - pyrenoid; $\mathrm{s}$ - starch grains; $\mathrm{t}$ - thylakoids; $\mathrm{v}$ - vacuole). Fig. 2 - a vegetative cell of Bracteacoccus minor (Chodat) Petrova; Fig. 3 - part of vegetative cell of Bracteacoccus minor (Chodat) Petrova (with nucleus and Golgi body); Figs 4-5 and 7 - a vegetative cell of Muriella decolor Vischer; Fig. 6 - part of pyrenoid of Muriella decolor Vischer (and starch grains). 

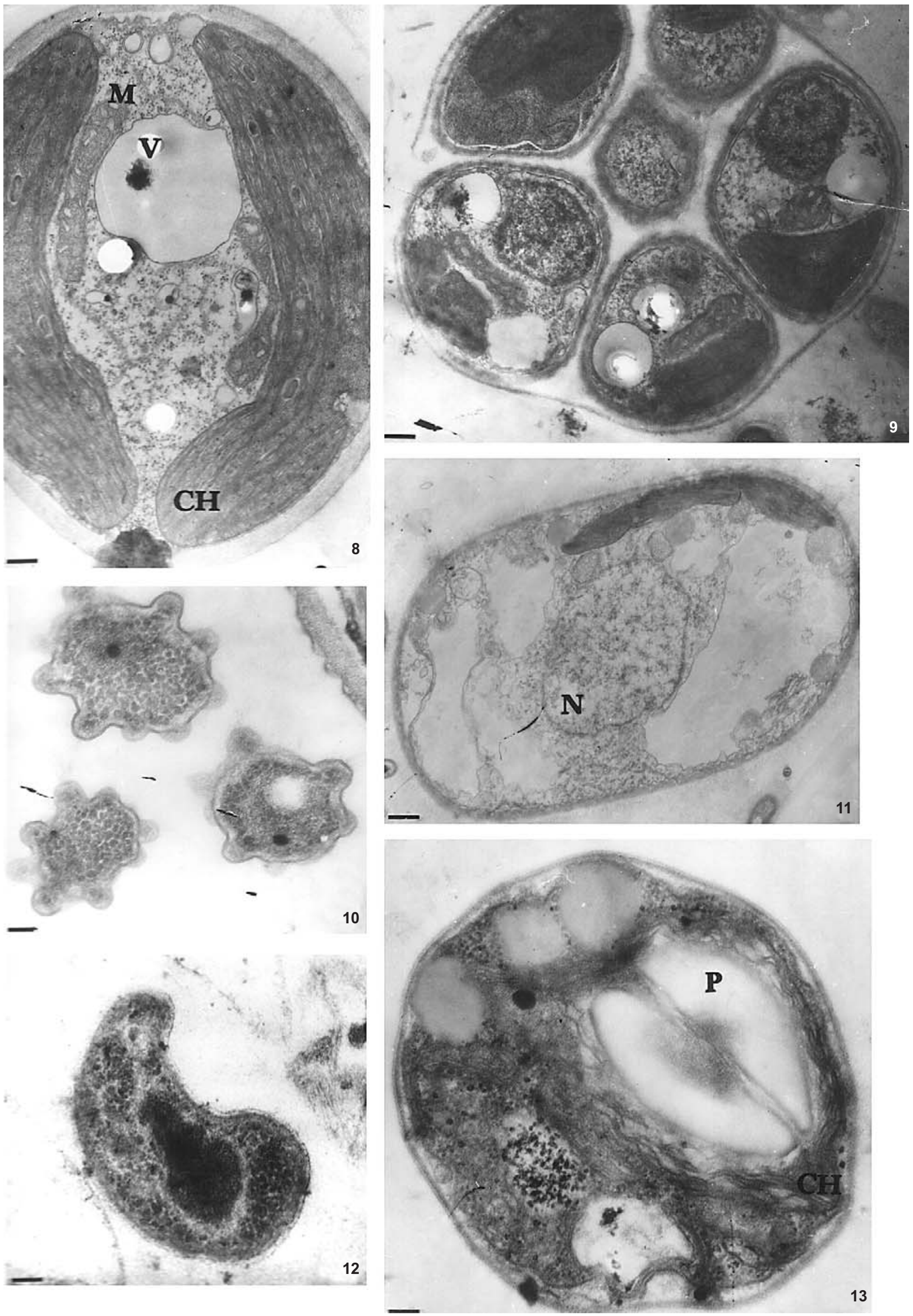

Figs 2-13. Cont.

Fig. 8 - part of vegetative cell of Tetracystis cf. isobilateralis Brown \& Bold; Fig. 9 - Tetracystis cf. isobilateralis Brown \& Bold (autosporangium with six autospores); Fig. 10 - Thelesphaera alpina Pascher; Fig. 11 - Trachychloron simplex Pascher (vegetative cell); Fig. 12 - Leptosira vischeri Reisigl (vegetative cell); Fig. 13 - a vegetative cell of Coleochlamys perforata (Lee et Bold) Ettl et Gärtner. All scale bars represent $1 \mu \mathrm{m}$. 
Leptosira vischeri Reisigl (Fig. 12)

Division: Chlorophyta

Class: Chlorophyceae

Vegetative cells 10-12 $\mu \mathrm{m}$ in diameter.

This species occurred in the Łabajowa Cave and Głęboka Cave. It is also known as an overground alga from Tyrol (Austria) (Ettl, Gärtner 1995).

Coleochlamys perforata (Lee et Bold) Ettl et Gärtner (Fig. 13) Division: Chlorophyta

Class: Chlorophyceae

Vegetative cells 18-32 $\mu \mathrm{m}$ long, 5-13 $\mu \mathrm{m}$ broad, cylindrical to oval. Cells with smooth cell walls. Chloroplast single and parietal with 1-2 pyrenoids. This species occurred in the Sąspowska Cave, Nietoperzowa Cave, Nad Matką Boską Cave and Twardowskiego Cave. It is also found in Romania (Caraus 2002) and Czech Republic and Slovakia (Ettl and Gärtner 1995).

\section{Gloeobotrys pyriformis Reisigl}

Division: Chrysophyta (Heterokontophyta)

Class: Xanthophyceae

Vegetative cells 13-15 $\mu \mathrm{m}$ long, 10-11 um broad, spherical or ellipsoid. Cells with smooth cell walls and small numbers of parietal chloroplasts without pyrenoids.

This species was found in the Glęboka Cave. Besides, it is known from the Alps (Tyrol, Austria) and recently found in Romania (Caraus 2002) and North Korea (Ettl and Gärtner 1995).

\section{Trachychloron biconicum Pascher}

Class: Xanthophyceae

Vegetative cells 9-16 um long.

This species occurred in Żarska Cave, Mamutowa Cave and Głęboka Cave. It was earlier known only from the Czech Republic and Austria.

\section{ACKNOWLEDGMENTS}

The authors are very grateful to dr Maciej Wayda (Jagiellonian University) for many helpful to collected material from each of caves. Sincere thanks are due to mgr inż. Krystyna Świeca (Depart. of Botany, UJK) for excellent technical assistance.

\section{LITERATURE CITED}

ABOAL M., ASENCIO A.D., PREFASI M. 1994. Studies on cave cyanophytes from southwestern Spain: Scytonema julianum (Menegh. \& Franck) Richter. Arch. Hydrobiol./Algological Studies 75: 31-36.

ASENCIO A.D., ABOAL M. 1996. Cyanophytes from Andragulla abrigo (Furcia, SE Spain) and their environmental conditions. Arch. Hydrobiol./Algological Studies 83: 55-72.

ASENCIO A.D., ABOAL M. 2000. A contribution to knowledge of chasmoendolithic algae in cave-like environments. Arch. Hydrobiol./Algological Studies 98: 133-151.

ASENCIO A.D., ABOAL M. 2000a. Algae from Serreta cave (Murcia, SE Spain) and their environmental conditions. Arch. Hydrobiol./Algological Studies 96: 59-78.

BROWN R.M. jr, BOLD H.C. 1964. Comparative studies of the algal genera Tetracystis and Chlorococcum. Phycological Studies V. Univ. Texas Publ. No 6417: 1-213.
BROWN R.M. jr, LEAN R.J. 1969. New taxonomic criteria in classification of Chlorococcum species. II. Pyrenoid fine structure. J. Phycol. 5: 114-118.

CARAUS I. 2002. The algae of Romania. Studii si Cercetari, Universitatea Bacau, Biologie 7: 1-694.

CARTER J.R. 1980. Diatoms from the Devil's Hole Cave. Scotland. Nova Hedwigia 71: 657-681.

CHANG T.P., CHANG-SCHNEIDER H. 1991. Algen in vier süddeutschen Höhlen. Ber. Bayer. Bot. Ges. 62: 221-229.

CLAUS G. 1962. Data on the ecology of the algae of the Peace Cave in Hungary. Nova Hedwigia 4: 55-80.

CLAUS G. 1962a. Beiträge zur Kenntnis der Algenflora der Abaligeter Höhle. Hydrobiologia 19: 192-222.

DEASON T.R., BOLD H. 1964. I Exploratory studies of Texas soil algae. Phycological Studies. University of Texas Publications. No 6022. Austin, Texas. 71.

DODGE J.D. 1984. Dinoflagellate Taxonomy. In: L. David, Spector, Dinoflagellates.

ETTL H. 1978. Xanthophyceae 1. Teil. In: H. Ettl, J. Gerloff, H. Heynig (eds), Süsswasserflora von Mitteleuropa. 3, G. Fischer Verlag. Stuttgart, New York. 530.

ETTL H., GÄRTNER G. 1988. Tetrasporales, Chlorococcales, Gloeodendrales, Chlorophyta II. In: H. Ettl, J. Gerloff, H. Heynig (eds), Süswasserflora von Mitteleuropa. G. Fischer Verlag, Stuttgart, New York. 453.

ETTL H., GÄRTNER G. 1995. Syllabus der Boden-, Luft und Flechtenalgen. G. Fischer Verlag. Stuttgart, Jena, New York. 720.

GOLUBIĆ S. 1967. Algenvegetation der Felsen. In: H.-J. Elster, W. Ohle (eds), Die Biennengewässer 23, Schweitzerbart'sche Verlagsbuchhandlung, Stuttgart, pp. 183.

GRADZIŃSKI M., GÓRNY A., SZELEREWICZ M. 1995. Jaskinie Ojcowskiego Parku Narodowego; Dolina Sąspowska; Wąwóz Jamki. Ojcowski Park Narodowy. Muzeum im. prof. Wł. Szafera, Ojców.

HAJDU L. 1966. Algological studies in the Cave of Mátyás Mount, Budapest, Hungary, Int. J. Speleol., 2, 137-149.

HELLEBUST J.A. 1974. Algal physiology and biochemistry. Blackwell Sci. Publ., Oxford, pp. 863.

JONES H.J. 1964. Algological investigations in Mammoth Cave, Kenteucky. Internal. J. Speleol. 1: 491-516.

KOL E. 1964. The microvegetation of a Small Ice-Cave in Hungary. Int. J. Speleol. 1: 19-24.

KOMÁROMY L.P. 1977. The algal flora of the Ördöglyuk Cave at Szoplak (Hungary). Ann. Hist. Natl. Rus. Natl. Hung. 69: 29-35.

KRAMMER K., LANGE-BERTALOT H. 1986. Bacillariophyceae 1. Teil: Naviculaceae. In: H. Ettl, J. Gerloff, H. Heynig, D.G. Mollenhauer (eds), Süsswasserflora von Mitteleuropa 2/1. Fischer Verlag. Stuttgart, New York, pp. 654.

KRAMMER K., LANGE-BERTALOT H. 1991. Bacillariophyceae 3. Teil: Centrales, Fragilariaceae, Eunotiaceae. In: H. Ettl, J. Gerloff, H. Heynig, D.G. Mollenhauer (eds), Süsswasserflora von Mitteleuropa 2/3, Fischer Verlag. Stuttgart, Jena, pp. 456.

MASSALSKI A., MROZIŃSKA T., OLECH M. 1995. Lobococcus irregularis (Boye-Pet.) Reisigl var. nov. (Chlorellales, Chlorophyta) from King George Island, South Shetland Islands, Antarctica, and ist ultrastructure. Nova Hedwigia 61 (1-2): 199-206.

MASSALSKI A., MROZIŃSKA T., OLECH M. 2001. Ultrastructural observations on five pionier soil alga from ice denuded areas (King George Island, West Antarctica). Polar Biosci. 14, 61-70.

MROZIŃSKA-BRODA T., CZERWIK-MARCINKOWSKA J. 2004. Eukariotic (epilithic) algae found in caves in the Kraków-Częstochowa Upland. In: J. Partyka (ed.), The diversification and transformation of natural and cultural environment of the Kraków-Częstochowa Upland. OPN, Ojców, 1: 171-178 . 
PENTECOST A. 1992. A note on the colonization of limestone rocks by cyanobacteria. Arch. Hydrobiol. 124: 167-172.

PENTECOST A., ZHANG Z. 2001. The distribution o plants in Scoska Cave, North Yorkshire, and their relationship to light intensity. Int. J. Speleol. 30: 27-37.

POULIČKOVÁ A., HAŠLER P. 2007. Aerophytic diatoms from caves in central Moravia (Czech Republic), Preslia 79: 185$-204$.

POULIČKOVÁ A. 2008. Morphology, cytology and sexual reproduction in the aerophytic cave diatom Luticola dismutica (Bacillariophyceae). Preslia 80: 87-99.

POPOVSKÝ J., PFIESTER L.A. 1990. Dinophyceae (Dinoflagellida). In: H. Ettl, J. Gerloff, H. Heynig, D. Mollenhauer (eds), Süsswasserflora von Mitteleuropa; 6. G. Fischer Verlag, Jena, Stuttgart. 272.
RAJCZY M. 1989. The Flora of Hungarien caves. Karsztés Barlang, Special Issue, 69-72.

STARMACH K. 1963. New species of the order Dinococcales (Pyrrophyta) from the Twardowski Cave in Kraków. Acta Hydrobiol. 3/4: 342-377.

STARMACH K. 1966. Cyanophyta - Sinice. Glaucophyta Glaukofity. Flora Słodkowodna Polski, 2. PWN, Warszawa, pp. 432.

STARZECKI W. 1959. Microclimatic research in caves of the southern part of Małopolska Highlands. Ekologia Polska, ser. A, VII, 7: 189-219.

SUBA E. 1957. Die Algen der Palvolgyes Höhle in Ungarn. Verh. Zool. - Bot. Ges. Wien. 97: 97-109.

SZELEREWICZ M., GÓRNY A. 1986. Jaskinie Wyżyny Krakowsko-Wieluńskiej. Drukarnia Narodowa, Kraków. 213. 